\title{
Some Mechanical Properties of Sugarcane at Different Sizes and Loadings Relevant to Design and Construction of Sugarcane Juice Extractor.
}

\author{
Oriola, K.O., Jekayinfa, S.O., Ola, F.A., Adedoyin, A.S. Akande, F.B.* \\ Department of Agricultural Engineering, LadokeAkintola University of Technology, Ogbomoso, Nigeria \\ Corresponding Author: Akande, F.B (fakande@lautech.edu.ng)
}

\begin{abstract}
This study evaluated the mechanical properties of two varieties of sugarcane; Saccharumofficinarum and Saccharumbarberi. Some mechanical properties (rupture force, rupture energy, bio-yield force, bio-yield energy and deformation at horizontal and vertical loading direction) were investigated using a Universal testing machine. Sugarcane is an economically important grass that is rich in calcium, chromium, cobalt and other health supportive substances. The stress undergone by the teeth while chewing sugarcane to obtain the juice content in addition to the inherent postharvest losseshas necessitated the study of its mechanical properties to enhance effective mechanization of its processing and handling.At sugarcane sizes (diameter) from 33-40, rupture force, rupture energy, bio-yield force, bio-yield energy and deformation are 2677 N, 11.15 N.m, 2828 N, 8.92 N.m and $7.32 \mathrm{~mm}$ respectively at vertical loading direction, and at horizontal loading direction rupture force, rupture energy, bio-yield force, bio-yield energy and deformation are 3157 N, 17.83 N.m, 3115 N, 11.43 N.m and $8.41 \mathrm{~mm}$ respectively for Saccharumofficinarum. At sugarcane sizes (diameter) from 30-37, rupture force, rupture energy, bio-yield force, bio-yield energy and deformation are 2890 N, 29.68 N.m, 2991 N, 5.98 N.m and $10.35 \mathrm{~mm}$ respectively at vertical loading direction, and at horizontal loading direction rupture force, rupture energy, bio-yield force, bio-yield energy and deformation are 3510 N, 35.95 N.m, 4574 N, 15.49 N.m and $12.78 \mathrm{~mm}$ respectively for Saccharumbarberi. The results will be useful in designing sugarcane harvester and sugarcane juice extractor.
\end{abstract}

Keywords: mechanical properties, sugarcane stalk diameter, sugarcane, juice extractor,

Date of Submission: 06-07-2017

Date of acceptance: 26-07-2017

\section{INTRODUCTION}

Sugarcane (Sacchariumspp) is a tall grass with a stout jointed and fibrous stalk that looks similar to bamboo [1]. It belongs to perennial herbs of a genus of the grass family Saccharium and tribe Andropogoneae[2]. It is extensively cultivated in tropical and subtropical regions of the world for the sugar contained within its stems. Sugarcane is known as Ireke in Yoruba, Okpete in Igbo and Reke in Hausa languages, in Nigeria. It is rich in calcium, chromium, cobalt, copper, magnesium, manganese, phosphorous, potassium and zinc [2]. It also contains iron and vitamins $\mathrm{A}, \mathrm{C}, \mathrm{B}_{1}, \mathrm{~B}_{2}, \mathrm{~B}_{3}, \mathrm{~B}_{5}$, and $\mathrm{B}_{6}$, plus a high concentration of phytonutrients (including chlorophyll), antioxidants, proteins, soluble fiber and numerous other health supportive compounds [2]. Matured sugarcane stalk is found to be composed of $11-16 \%$ fiber, $12-16 \%$ soluble sugars, $2-3 \%$ nonsugars, and $63-73 \%$ water [1].The current estimated sugarcane production of the nation as at 2008 was put at over $1.4 \mathrm{~m}$ tones [3]. The varieties of sugarcane available in Nigeria and the world in general as of today as not been estimated but [4] and [5]categorized the types of sugarcane in Nigeria into Industrial (Saccharumofficinarum) and Local Chewing Sugarcane (Saccharumbarberi). In subSahara African Countries, the suckle in sugarcane has been enjoyed by using teeth to bite off the rind and chewing off the internal tissues, then the juice is sucked in the mouth and the bagasse is spat out. This consumption method is considered to be grossly; unhealthy and uncivil aside the stress the teeth have to undergo [6]. Hence mechanization of sugarcane processing is not only necessary to meet the need for fresh sugarcane juice but also for reducing the postharvest loss in sugarcane. Hence, an engine powered sugarcane juice extractor is essential for small and medium scale farmers. Keeping the above factors in mind, some properties of sugarcane pertaining to the crushing of sugarcane and extraction of juice is conducted for the design of an engine powered sugarcane extractor. The design of the major units such as the crushing unit, engine motor selection, the separation unit is dependents on the properties. A lot 
of researches have been reported on sugarcane such as physical properties of sugarcane [7], characteristics of sugarcane fibres[8].Quasi-static tests using a universal testing machine to determine shear, compressive resistance and bending resistance of forage crops[9]. Investigation of the mechanical properties of sugarcane stalks viz; bending resistance, cutting resistance, penetration resistance and crushing resistance for the development of a whole cane combine harvester [10]. Based on the review of previous work on sugarcane, the variation in sizes of sugarcane from one internodes to another has not been considered to see their effect on the mechanical properties of sugarcane, its becomes of interest to investigate if the variation in sizes will have effect on its mechanical properties. The specific objective of this study is to determine some mechanical properties of sugarcane namely rupture force, rupture energy, bio-yield force, bio-yield energy and deformation at rupture point over a range of some selected sugarcane size (diameter).

\section{MATERIALS AND METHODS}

\subsection{Sample Preparation}

Two sugarcane varieties used for this study were sourcedfrom OjaGboro in Ilorin, Kwara State, Nigeria. The two varieties are;Saccharumofficinarum(Industrial)and

Saccharumbarberi(Local Chewing) sugarcane, which were peeled and unpeeled, and replicated three times, under vertical and horizontal loading direction. (Plate 1 and 2), this combined gives and experimental design of $2 \times 2 \times 2 \times 3$. Theywerecut into thesamesizes of $10 \mathrm{~cm}$ (average size of a sugarcane node)with twelve (12) samples for each variety making atotal of twenty four (24) samples for the analysis.

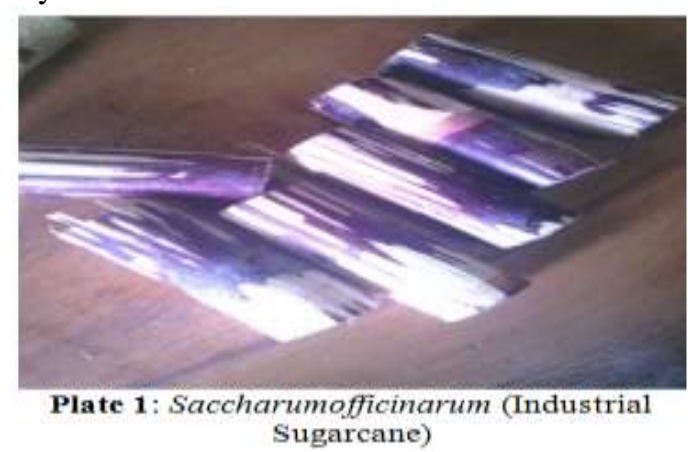

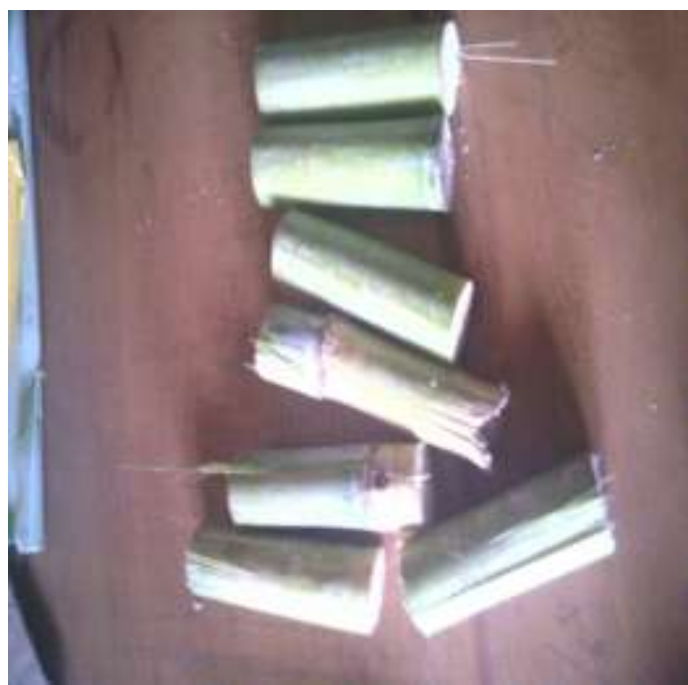

Plate 2: Saccharumbarberi (Local Chewing Sugarcane)

\subsection{Diameter of Sugarcane}

The diameter of sugarcane varies from bottom to top and this variation depends upon the variety and the climatic condition which prevailed in the growth phase of the sugarcane [7]. Sugarcane diameter plays a significant role in the design of rollers used in sugarcane extractor and in the selection of the maximum and minimum clearance between the rollers. The diameters of the two varieties of sugarcane used in the compression test were carefully selected with the help of a vernier caliper with code number 532-120, 0-200 mm range and accuracy of $\pm 0.01 \mathrm{~mm}$ and taken as minimum, mean and maximum in the range as shown in Table 1 for horizontal and vertical loading as reported by[7][11].

Table 1: Some selected sugarcane diameter

\begin{tabular}{|l|c|c|c|}
\hline Variety & \multicolumn{1}{c|}{ min. dia.(mm) } & mean dia. (mm) & \multicolumn{1}{c|}{ max. dia.(mm) } \\
\hline Saccharumofficinarum & 33 & 36 & 40 \\
\hline Saccharumbarberi & 30 & 34 & 37 \\
\hline
\end{tabular}

\subsection{Mechanical properties}

The compression tests were carried out using a Universal testing machine that is equipped with a $50 \mathrm{~kg}$ compression load cell and integrator with machine number 0500-10080. The measurement accuracy was $0.001 \mathrm{~N}$ and $0.001 \mathrm{~mm}$ in deformation [12]. The rupture force, rupture energy, bio-yield force, bio-yield energy and deformation at rupture point were determined from the vertical and horizontal loading position; at a loading speed of 5 
$\mathrm{mm} / \mathrm{min}$ [13]. An individual sample of the sugarcane was placed on the lower plate (Plate.3a and b) and the top section attached to the chuck moved downward with a constant speed until fracture occurred as it is denoted in the force - deformation curve (Plate 4). The loading is stopped once the fracture was detected. Three replicates were made for each loading.

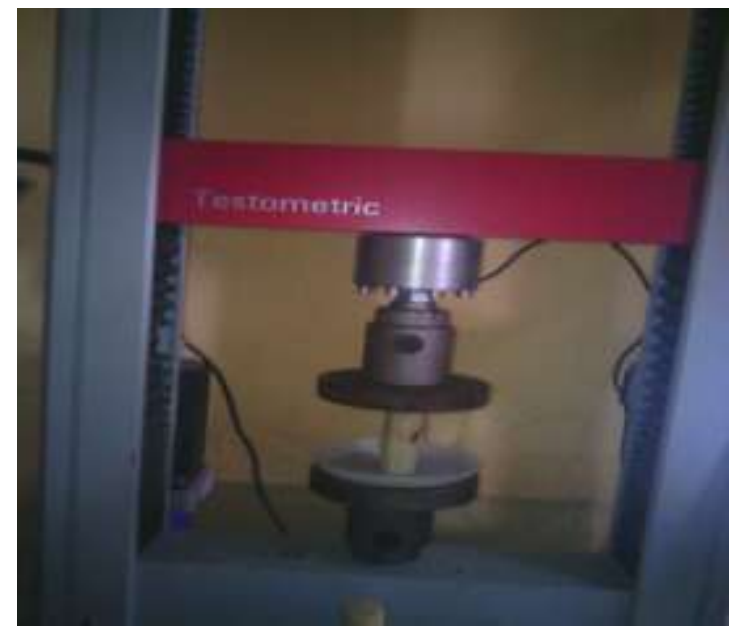

Plate 3a: Compressive test for peeled sugarcane sample

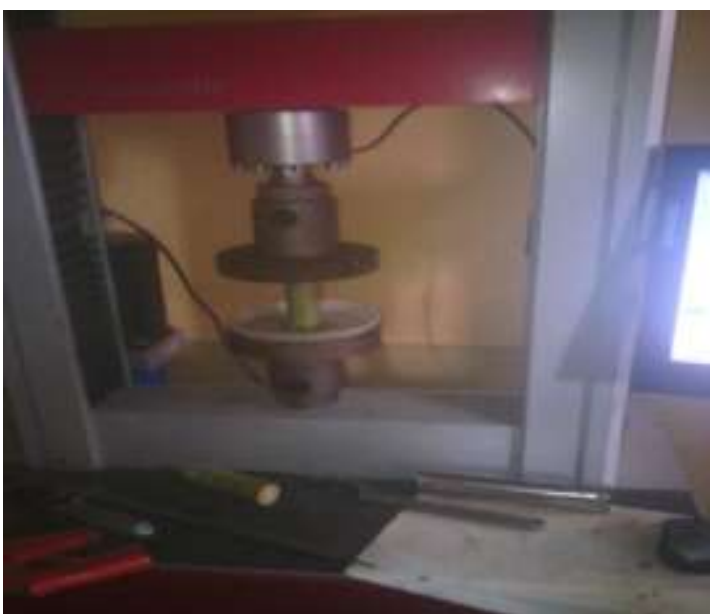

Plate 3b: Compressive test for unpeeled sugarcane sample

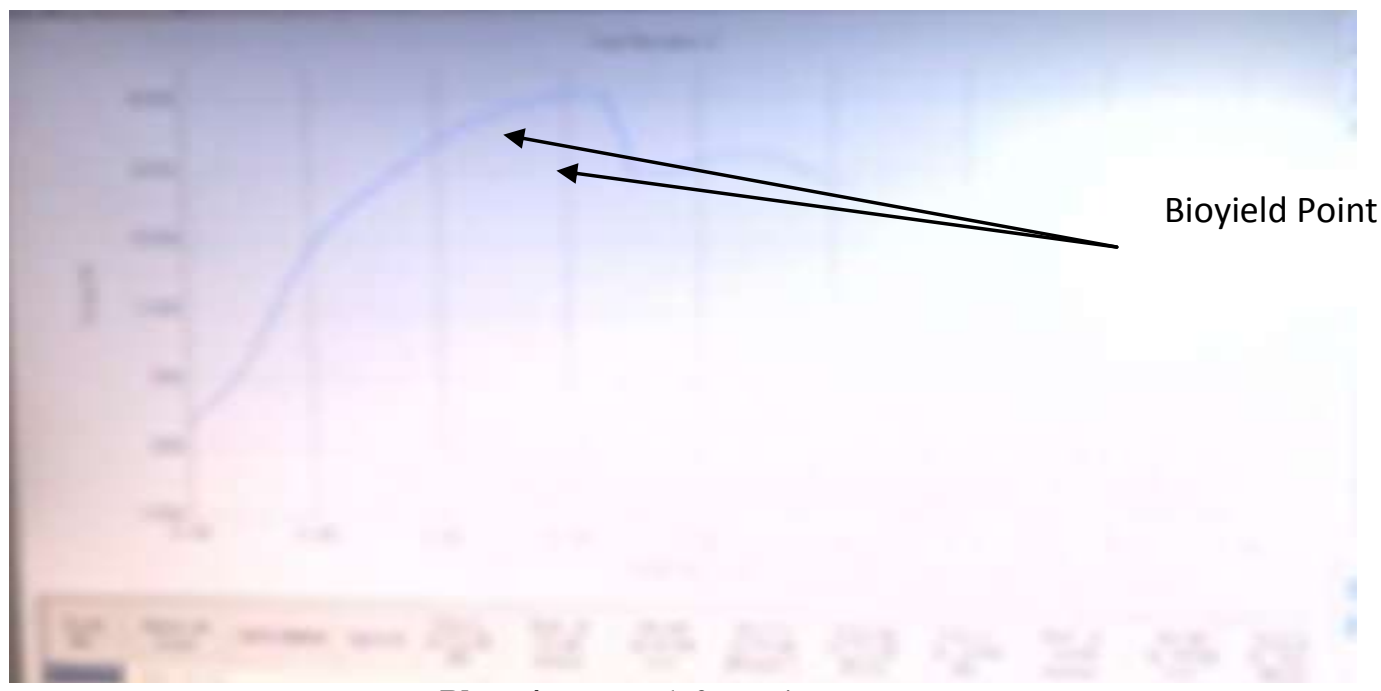

Plate 4: Force- deformation curve

\subsection{Analysis of results}


The data obtained were analysed using Analysis of Variance (ANOVA) and regression in Minitab 16.2.1 software (2010 Minitab Inc.) to determine the effects of different sizes (diameter) on the mechanical properties of industrial and local chewing sugarcanevarieties

\section{RESULTS AND DISCUSSION}

Results of the compressive tests conducted on the two sugarcane varieties are presented is Table 2.

Table 2. Mechanical properties of sugarcane at vertical and horizontal loading directions analysed by Duncan multiple range test $(\mathrm{p} \leq 0.05)$

\begin{tabular}{|c|c|c|c|}
\hline Properties & Min. & Max. & \\
\hline \multicolumn{4}{|c|}{ Sacchariumofficinarum } \\
\hline \multicolumn{4}{|c|}{ Vertical loading direction } \\
\hline Rupture force $(\mathrm{N})$ & $2677.00 \pm 16.12^{b}$ & $2891.33 \pm 23.45^{b}$ & $3157.00 \pm 49.33^{b}$ \\
\hline Rupture energy (N.m) & $11.15 \pm 0.04^{\mathrm{a}}$ & $14.16 \pm 0.10^{\mathrm{a}}$ & $17.83 \pm 0.56^{\mathrm{a}}$ \\
\hline Bio-yield force $(\mathrm{N})$ & $2828.00 \pm 3.71^{\mathrm{c}}$ & $2992.00 \pm 26.29^{c}$ & $3115.00 \pm 34.57^{b}$ \\
\hline Bio-yield energy (N.m) & $8.92 \pm 0.20^{\mathrm{a}}$ & $10.49 \pm 0.07^{\mathrm{a}}$ & $11.43 \pm 0.14^{\mathrm{a}}$ \\
\hline Deformation $(\mathrm{mm})$ & $7.32 \pm 0.10^{\mathrm{a}}$ & $7.71 \pm 0.21^{\mathrm{a}}$ & $8.41 \pm 0.06^{\mathrm{a}}$ \\
\hline \multicolumn{4}{|c|}{ Horizontal loading direction } \\
\hline Rupture force $(\mathrm{N})$ & $1073.00 \pm 22.27^{b}$ & $1360.33 \pm 104.00^{b}$ & $1586.00 \pm 55.57^{b}$ \\
\hline Rupture energy (N.m) & $3.09 \pm 0.06^{\mathrm{a}}$ & $4.47 \pm 0.14^{\mathrm{a}}$ & $6.90 \pm 0.27^{\mathrm{a}}$ \\
\hline Bio-yield force $(\mathrm{N})$ & $1609.00 \pm 7.62^{\mathrm{c}}$ & $1617.33 \pm 68.05^{\mathrm{c}}$ & $1630.00 \pm 60.65^{b}$ \\
\hline Bio-yield energy (N.m) & $1.73 \pm 0.01^{\mathrm{a}}$ & $2.26 \pm 0.07^{\mathrm{a}}$ & $2.56 \pm 0.15^{\mathrm{a}}$ \\
\hline Deformation $(\mathrm{mm})$ & $3.28 \pm 0.08^{\mathrm{a}}$ & $4.71 \pm 0.37^{\mathrm{a}}$ & $6.45 \pm 0.15^{\mathrm{a}}$ \\
\hline \multicolumn{4}{|c|}{ Saccharumbarberi } \\
\hline \multicolumn{4}{|c|}{ Vertical loading direction } \\
\hline Rupture force $(\mathrm{N})$ & $2890.00 \pm 57.33^{b}$ & $3235.00 \pm 64.17^{b}$ & $3510.00 \pm 23.25^{b}$ \\
\hline Rupture energy (N.m) & $29.68 \pm 1.18^{\mathrm{a}}$ & $33.64 \pm 0.93^{\mathrm{a}}$ & $35.95 \pm 0.68^{\mathrm{a}}$ \\
\hline Bio-yield force $(\mathrm{N})$ & $2991.00 \pm 45.83^{b}$ & $3974.33 \pm 30.04^{\mathrm{ab}}$ & $4574.00 \pm 38.92^{\mathrm{c}}$ \\
\hline Bio-yield energy (N.m) & $5.98 \pm 0.29^{\mathrm{a}}$ & $11.94 \pm 0.32^{\mathrm{a}}$ & $15.49 \pm 0.46^{\mathrm{a}}$ \\
\hline Deformation $(\mathrm{mm})$ & $10.35 \pm 0.13^{\mathrm{a}}$ & $11.43 \pm 0.16^{\mathrm{a}}$ & $12.78 \pm 0.26^{\mathrm{a}}$ \\
\hline \multicolumn{4}{|c|}{ Horizontal loading direction } \\
\hline Rupture force $(\mathrm{N})$ & $573.00 \pm 9.01^{b}$ & $855.33 \pm 16.15^{b}$ & $1316.00 \pm 32.07^{\mathrm{c}}$ \\
\hline Rupture energy (N.m) & $1.41 \pm 0.09^{\mathrm{a}}$ & $2.74 \pm 0.05^{\mathrm{a}}$ & $4.83 \pm 0.06^{\mathrm{a}}$ \\
\hline Bio-yield force $(\mathrm{N})$ & $898.00 \pm 5.81^{\mathrm{c}}$ & $1014.67 \pm 4.61^{\mathrm{c}}$ & $1203.00 \pm 31.01^{b}$ \\
\hline Bio-yield energy (N.m) & $0.89 \pm 0.05^{\mathrm{a}}$ & $1.16 \pm 0.04^{\mathrm{a}}$ & $1.29 \pm 0.08^{\mathrm{a}}$ \\
\hline Deformation $(\mathrm{mm})$ & $3.19 \pm 0.06^{\mathrm{a}}$ & $3.91 \pm 0.05^{\mathrm{a}}$ & $4.96 \pm 0.09^{\mathrm{a}}$ \\
\hline
\end{tabular}

$a, b, c:$ Means superscript with different letters in the same row differ significantly

\subsection{Rupture Force:}

The rupture force of the Industrial and local chewing sugarcane varieties at the two loading directions are presented in Fig. 1. The rupture force of Saccharumofficinarumincreases linearly from 2677 to $3157 \mathrm{~N}$ for vertical and non-linearly from 1073 to $1586 \mathrm{~N}$ for horizontal as the sugarcane size or diameter increases from 33 to $40 \mathrm{~mm}$ and so also the rupture force of the Saccharumbarberi increases linearly from 2890 to $3510 \mathrm{~N}$ for vertical and quadratically from 573 to $1316 \mathrm{~N}$ for horizontal as the sugarcane size or diameter increases from 30 to $37 \mathrm{~mm}$. The force required to fracture the industrial sugarcane at vertical direction was significantly higher than for horizontal position $(\mathrm{p} \leq 0.05)$ at all experimental diameters for both sugarcane varieties. Similar results were reported by [14] on mechanical properties of kenaf stems at varying moisture content, [15] on mechanical properties of cassava stalks and [16] on physical and mechanical characteristics for some agricultural residue such as cotton stalk, maize stalks and sugarcane bagasse which are reported for different directions. The relationship between the sample rupture forces with different diameters at vertical and horizontal loading directions for Saccharumofficinarum andSaccharumbarberiwas significantly correlated $(\mathrm{p} \leq 0.05)$ and can be expressed using equations 1 to 4 .

Saccharumofficinarum

$R_{f}=421+68.5 D_{i} R^{2}=0.999($ Vert. direction)(1)

$R_{f}=-1290+72.4 D_{i} R^{2}=0.977$ (Hor. direction)(2)

Saccharumbarberi

$R_{f}=234+88.4 D_{i} R^{2}=0.999$ (Vert. direct.) (3)

$R_{f}=-2594+104 D_{i} R^{2}=0.952$ (Hor. direction)(4)

Where;

$R_{f}$ is the rupture force $(\mathrm{N})$ and

$D_{i}$ is the diameter of sugarcane $(\mathrm{mm})$.

Crushing and juice extraction is a subject of rupture force and the diameter of the sugarcane. Therefore, for the design of a sugar cane juice extractor, the values of the rupture force will be needed for the selection of the pulley or sprocket so as to determine the required speed that will supply the force needed to extract the juice from the sugarcane. 


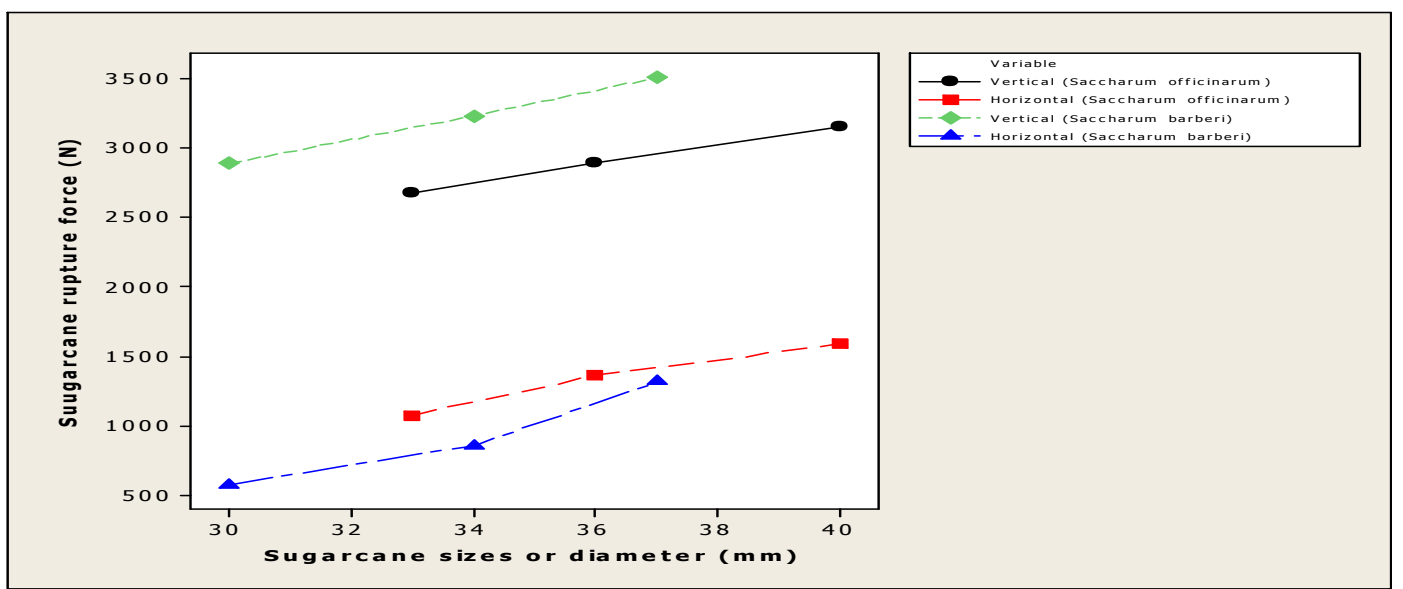

Figure 1:Effect of different sugarcane diameter on rupture force of Saccharumofficinarum and Saccharum barberi

\subsection{Rupture Energy}

The rupture energy of the Industrial and local chewing cane is shown in Fig. 2. Rupture energy was greater forSaccharumbarberithan Saccharumofficinarumat vertical loading but lower forSaccharumbarberithan Saccharumofficinarumat horizontal loading. The rupture energyincreases for Saccharumofficinarumfrom 11.15 to 17.83 N.m and Saccharumbarberifrom 29.68 to 35.95 N.m at vertical loading, so also increases at horizontal loading for Saccharumofficinarumfrom 3.09 to 6.90 N.m and Saccharumbarberifrom 1.41 to 4.80 N.m. There is a clear difference in the rupture energy for both varieties as it is known that Saccharumbarberi is harder and have smaller diameter than Saccharumofficinarum. The results are similar to those reported by[17] on mechanical characteristics for cotton and pigeon pie as agricultural residue and [14] on mechanical properties of kenaf stems at varying moisture content but are not reported for different direction which is important to machine design. In vertical and horizontal direction of loading, rupture energy shows a strong significant $(\mathrm{P} \leq 0.05)$ correlation to a size of sugarcane (diameter)

The relationship between rupture energy and size of sugarcane (diameter) at vertical and horizontal loading directions for Saccharumofficinarum and Saccharumbarberiareshown using the regression equations 5 to 8 .

\section{Saccharumofficinarum}

$R_{e}=-20.2+0.95 D_{i} R^{2}=0.999$ (vert. direct.) (5)

$R_{e}=-15.1+0.548 D_{i} R^{2}=0.994$ (Hor. direct) $(6)$

Saccharumbarberi

$R_{e}=2.76+0.901 D_{i} R^{2}=0.995$ (Vert. direct) (7)

$R_{e}=-13.0+0.47 D_{i} R^{2}=0.958$ (Horiz. direct) $(8)$

Where;

$R_{e}$ is the rupture energy (N.m)

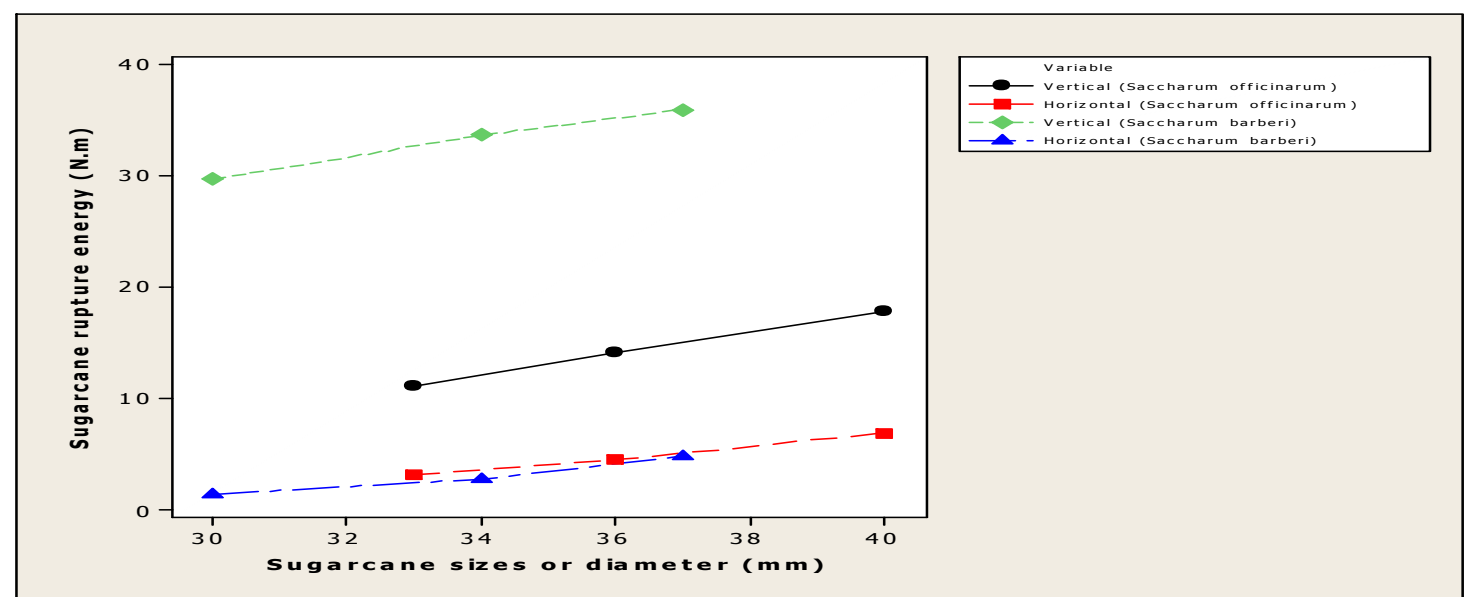

Figure 2:Effect of different sugarcane diameter on rupture energy of Saccharumofficinarum and Saccharumbarberi

\subsection{Bio-yield force and energy}

The bio-yield force and energy of the SaccharumofficinarumandSaccharumbarberiare shown in Figs. 3 and 4, respectively. The bio-yield force for Saccharumofficinarumat vertical and horizontal loading increases from 2828 to $3115 \mathrm{~N}$ and 1609 to $1630 \mathrm{~N}$, respectively at the sugarcane size of 33 to $40 \mathrm{~mm}$ while the 
Saccharumofficinarumbio-yield force at both verticaland horizontal direction increases from 2991 to $4574 \mathrm{~N}$ and 898 to $1203 \mathrm{~N}$, respectively at the sugarcane size of 30 to $37 \mathrm{~mm}$. Similar findings were reported by [18] for bio-yield force of pods of proposes Africana and [19] on mechanical properties of Carob pod (CeratoniaSiliqua L.). Bio-yield force is greater than rupture force in all loading directions, and it is observed from the result that the bio-yield force for Saccharumofficinarumis higher at horizontal direction than the Saccharumbarberi, this may be due to the fact that Saccharumbarberigenerally are smaller in diameter and harder than Saccharumofficinarum. At vertical and horizontal loading direction, the bio-yield energy for industrial and local chewing sugarcane increases linearly from 8.92 to 11.43 N.m, 1.72 to 2.56 N.m, 5.98 to 15.49 N.m and non-linearly from 0.89 to 1.29 N.m respectively. The relation between bio-yield force, bio-yield energy and the size of sugarcane (diameter) for Saccharumofficinarum and Saccharumbarberiunder vertical and horizontal loading was significantly correlated $(\mathrm{p} \leq 0.05)$ and can be expressed using equations 9 to 16 .

Saccharumofficinarum

$B_{f}=1509+40.4 D_{i} R^{2}=0.973$ (Vert. direct.) (9)

$B_{e}=-2.51+0.352 D_{i} R^{2}=0.950($ Vert. direct $)(10)$

$B_{f}=1509+3.01 D_{i} R^{2}=0.999$ (Hor. direct.) (11)

$B_{e}=-2.09+0.118 D_{i} R^{2}=0.941$ (Hor. direct) (12)

\section{Saccharumbarberi}

$B_{f}=-3803+227 D_{i} R^{2}=0.997$ (Vert. direct.) (13)

$B_{f}=-402+42.8 D_{i} R^{2}=0.954$ (Vert. direct.) (14)

$B_{e}=-34.8+1.37 D_{i} R^{2}=0.996$ (Hor. direct) (15)

$B_{e}=-0.829+0.057 D_{i} R^{2}=0.986($ Hor.direct $)(16)$

Where;

$B_{f}$ is the bio-yield force $(\mathrm{N})$,

$B_{e}$ is the bio-yield energy (N.m),

$D_{i}$ is the diameter of sugarcane $(\mathrm{mm})$.

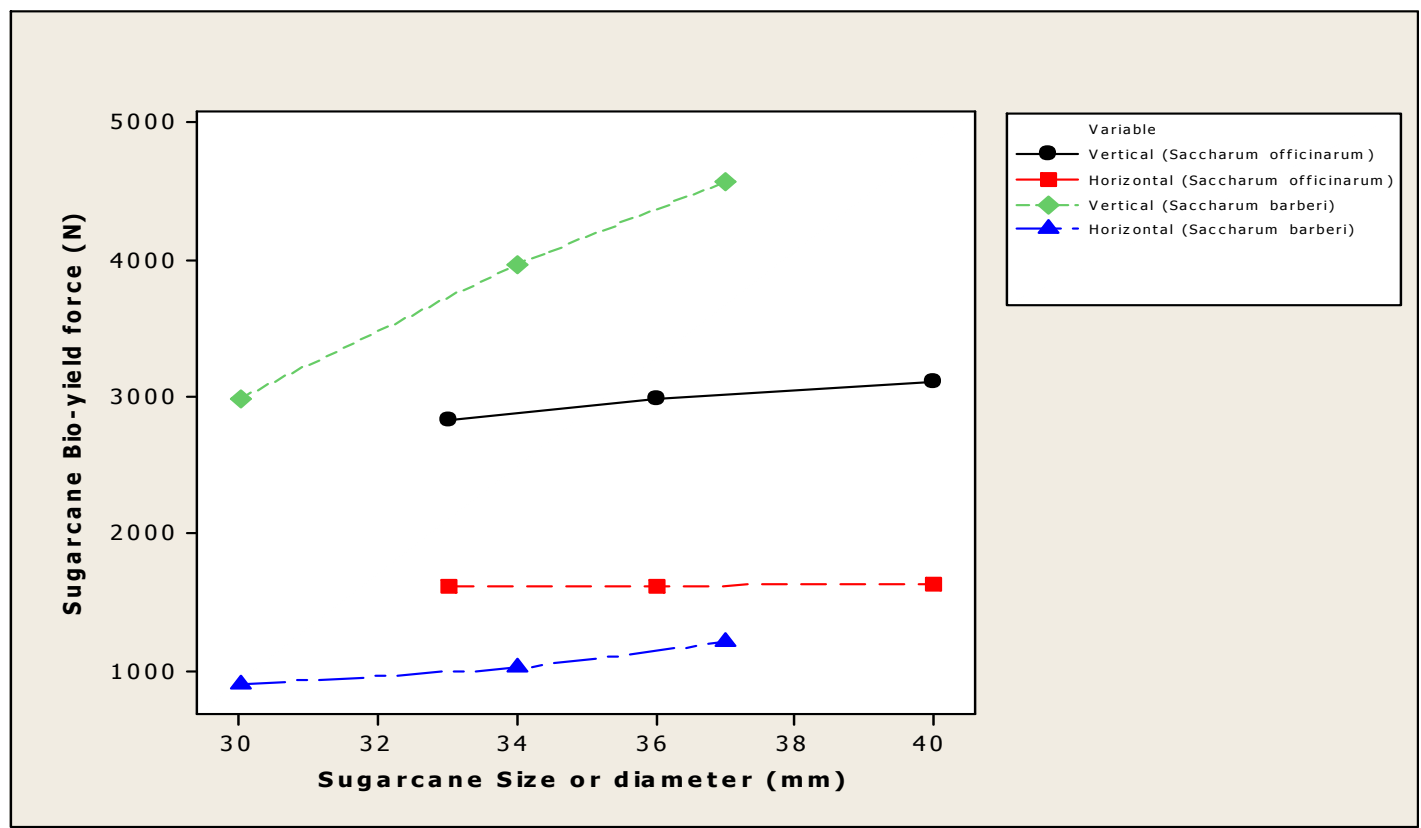

Figure 3:Effect of different sugarcane diameter on bio-yield force of Saccharumofficinarum and Saccharumbarberi 


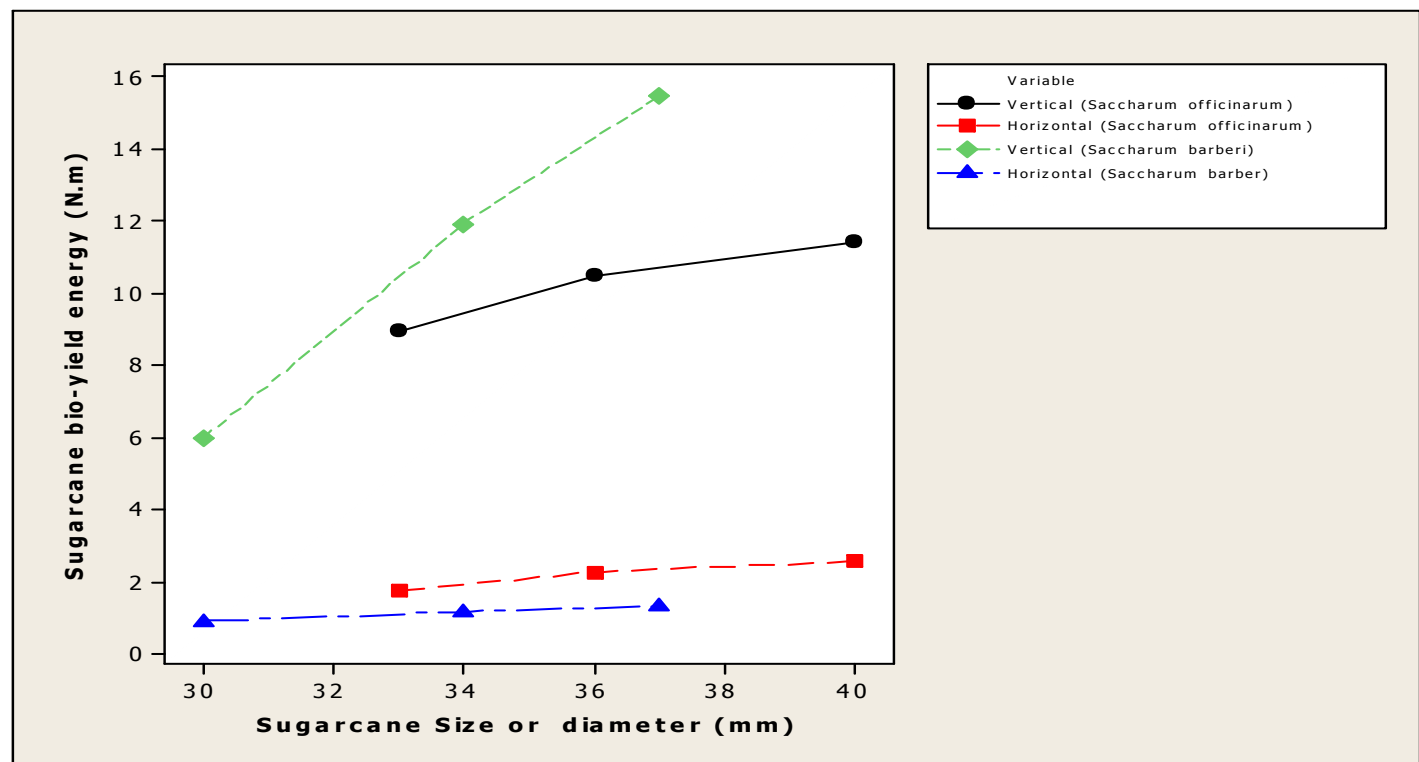

Figure 4: Effect of different sugarcane size or diameter on bio-yield energy ofSaccharumofficinarumand Saccharumbarberi

\subsection{Deformation at rupture point:}

The deformation at rupture point is presented in Fig 5 for both Industrial and Local chewing sugarcane at vertical and horizontal loading direction. The deformation for Saccharumofficinarum increases from 7.32 to $8.41 \mathrm{~mm}$ in vertical loading direction and 3.28 to $6.45 \mathrm{~mm}$ in horizontal loading direction, while for Saccharumbarberi increases from 10.35 to $12.78 \mathrm{~mm}$ in vertical loading direction and 3.19 to $4.96 \mathrm{~mm}$ in horizontal loading direction. It was observed that the deformation is higher for Saccharumbarberi in vertical loading direction than for industrial sugarcane and vice versa in horizontal loading direction. Similar findings were reported by [20]on some mechanical properties of agbaraba-a native Nigeria bamboo but were not reported for different direction.

The relationship between deformation and different sizes of sugarcane (diameter) at vertical and horizontal loading for SaccharumofficinarumandSaccharumbarberiwas significantly correlated $(p \leq 0.05)$ and $c a n$ be expressed respectively using the equation 17 to 20 .

Saccharumofficinarum

$D_{r p}=2.12+0.157 D_{i} R^{2}=0.99$ (Vert. direct.) (17)

$D_{r p}=-11.6+0.452 D_{i} R^{2}=0.99$ (Hor. direct)(18)

\section{Saccharumbarberi}

$D_{r p}=-0.03+0.343 D_{i} R^{2}=0.97$ (Vert. direct) (19) $D_{r p}=-4.36+0.249 D_{i} R^{2}=0.965$ (Hor. direct) $(20)$

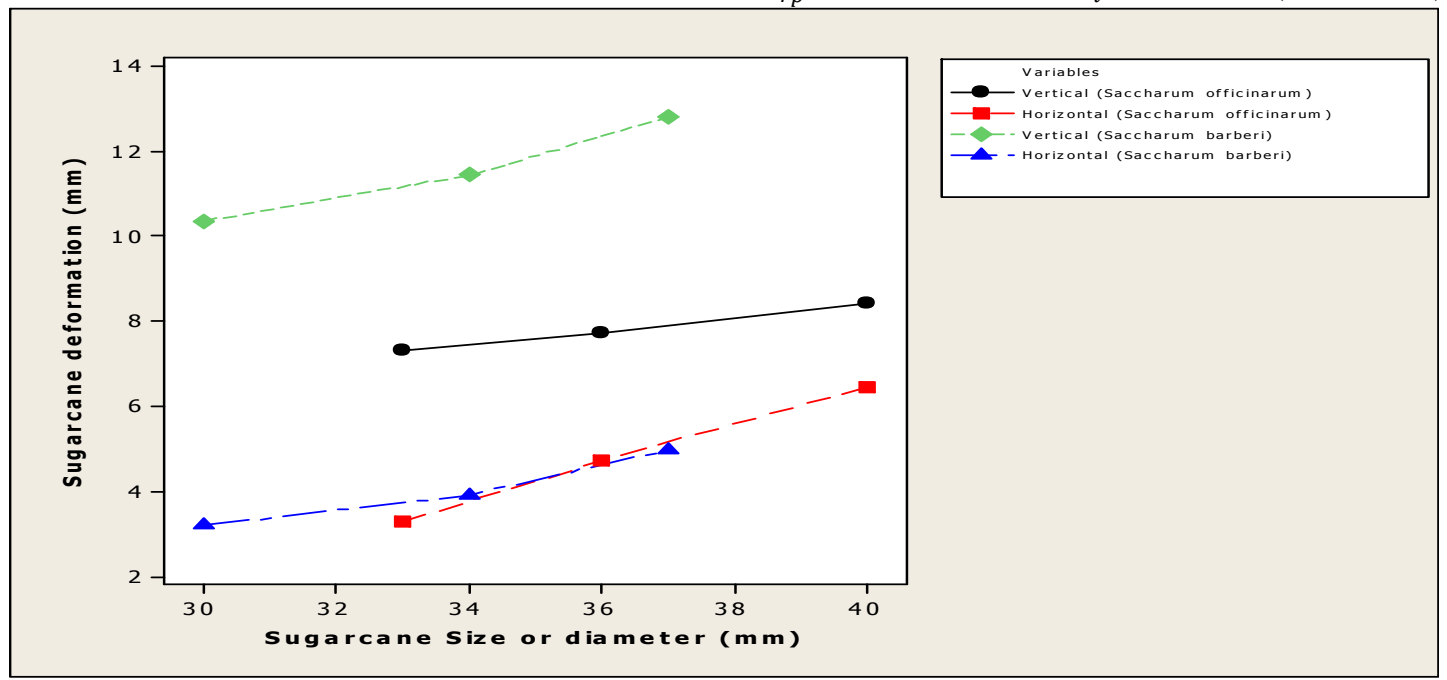

Figure 5: Effect of different sugarcane size or diameter on deformation of Saccharumofficinarumand Saccharumbarberi

IV. CONCLUSION
Some of the mechanical properties required for the design and fabrication of sugarcane juice 
extractor have been determined (the rupture force and energy, bio-yield force and energy, and deformation). The mechanical properties are function of the sugarcane size, an adjustable mechanism will be necessary in the construction of a sugarcane extractor to accommodate different sizes of sugarcane. Data obtained will be useful in the design of sugarcane crusher, juice extractor and other sugarcane processing machine.

\section{ACKNOWLEDGMENT}

The researchers are grateful for the Tetfund University based research grant awarded for this project under the TETFUND INTERVENTION PROJECT REF: TETFUND/DESS /LAUTECH/OGBOMOSO/RP/VOL. VI

\section{REFERENCES}

[1] McCaffrey, D. Raw Sugarcane Juice Nature's Perfect Wonder Food, Newspaper Article, 2011,http://www.processsedfreeamerica.org/in dex.php?option $=$ com content $\&$ view $=$ article \&i $=535$ :raw-sugarcane-juicenatures-perfectwonder-

food\&catid=37: healthnews\&itemid=72. Retrieved on Monday, October 03, 2015.pp 16.

[2] Priya, D.K. and Lakshmi, Y.V. Sugarcane Juice Vending Machines and Vendors Problems and Prospects.International Journal of Science and Research (IJSR),3(11), 2012, 3017-3074.

[3] Aina, O.S., Ajijola, S., Ibrahim, I., Musa, I.A. and Bappah, T. M. Economics Analysis of Sugarcane (saccharumofficinarum) Production in Moro Local GovernmentArea of Kwara State, Nigeria. International Research Journal of Plant Science,6(1), 2015, 1-6.

[4] Agidi, G. Development and Testing of Sugarcane Juice Extractor. Society for Sugar Research and Promotion, 4(3\&4), 2002, 103107.

[5] Nmadu, J. N.,Ojo M.A, and Ibrahim F.D. Prospects of Sugar Production and Imports: Meeting the Sugar Demand of Nigeria by Year 2020. Russian Journal of Agricultural and Socio-Economic Sciences, 2(3), 2014, 15-25.

[6] Makinde-Ojo, A.M.Improvement of the Fabrication and testing of a Sugarcane Juice Extractor for the Cottage Industry [Electronic version], B.Eng project report. Department of Agricultural Engineering, University of Agriculture Abeokuta,Nigeria, 2010.

[7] Bastian J and Shridar B.Physical Properties of Sugar Cane Pertaining to the Design of a Whole Stalk SugarCane Harvester. International Journal of Engineering
Sciences\& Research Technology, 3(11), 2014a, 167-172.

[8] Asagekar, S.D. and Joshi, V.K. Characteristics of Sugarcane Fibres. India Journal of Fibre and Textile Research, 3(9), 2014, 180-184.

[9] Chattopadhyay, P.S. and Pandy, K.S.Effect of Knife and Operational Parameters on Energy Requirement in Flail Forage Harvesting. Journal of Agricultural Engineering Resources,7(3), 1999 3-12.

[10] Bastian, J. and Shridar, B. Investigation on mechanical properties of sugarcane stalks for the Development of a Whole Cane Combine Harvester. India Journal of Applied Research, 4(9), 2014b 1-3.

[11] Olawuyi, O.O. Design and Fabrication of a Motorized Sugarcane Juice Extractor,B.Tech Project Report, Department of Agricultural Engineering, LadokeAkintolaUniversity of Technology, Ogbomoso, Nigeria, 2014.

[12] Ahmadi, R., Kalbasi-Ashtari A., and Gbaribzahedi, S.M.T. Physical Properties of Psyllium Seed. Int. Agrophys,2(6), 2012, 91-93.

[13] ASABE, (2004). Compression Test of Food Material of Convex Shape: ASAE S368.4. ASAE Standard 2004: 580-592.

[14] Dauda, S.M., Ahmad, D., Khalima, A. and Jamarei, O. Physical and Mechanical Properties of Kenaf Stems at Varying Moisture Content. Agricultural and AgriculturalScience Procedia, 2(6), 2014, 370-374.

[15] Xue, Z., Zhang, J., Zhang, Y.L., Li, C.B. and Chen S. (2015).Test and Analysis on the Mechanical Properties of Cassava Stalks. The Journal of Animal and Plant Sciences, 25(3), 2015, 59-67.

[16] Esissa, A.H., Gomaa, A.H., Baiomy, M.H. and Ibrahim, A.A. Physical and Mechanical Characteristics for some Agricultural Residue. Journ.of Ag. Eng, 25(1), 2008, 121-146.

[17] Sonde, V.M., Belkhode P.N. and Sakhale, C.N.Physical and Mechanical Characteristics for Cotton and Pigeon Pie as Agriculture Residue. International Journal of Application orInnovation in engineering management, 4(7), 2015, 156-159.

[18] Adigun, Y.J. and Alonge A.F. Some Engineering Properties of Prosopis Africana Pods Relevant Dehulling.Niger. J.Technol, 19(1), 2000, 52-58.

[19] K. Ekinci, D. Yilmaz and C. Ertekin.Effects of Moisture Contents and Compression Position on Mechanical Properties of Carob Pod (CeratoniaSiliqua L.).African Journal of Agricultural Research, 5(10), 2010, 10151021. 
[20] Adedipe, O., Abdullahi, A.A., Ogunwole, O.A. and Ogu, S.I. Investigation of Some Mechanical Properties of Agaraba - A Native
Nigeria Bamboo. Australia Journal of Technology, 16(3), 2013, 181-186.

Oriola. "Some Mechanical Properties of Sugarcane at Different Sizes and Loadings Relevant to Design and Construction of Sugarcane Juice Extractor." International Journal of Engineering Research and Applications (IJERA) 7.7 (2017): 62-70. 